\title{
Kribbella hippodromi sp. nov., isolated from soil from a racecourse in South Africa
}

\author{
Gareth J. Everest and Paul R. Meyers \\ Department of Molecular and Cell Biology, University of Cape Town, Private Bag 1, Rondebosch, \\ 7701 Cape Town, South Africa
}

Correspondence

Paul R. Meyers

paul.meyers@uct.ac.za

\begin{abstract}
A novel actinomycete, designated strain $S 1.4^{\top}$, was isolated from a soil sample collected from Kenilworth Racecourse in the Western Cape, South Africa. The strain was able to grow in the presence of $5 \% \mathrm{NaCl}$. It contained LL-diaminopimelic acid and glycine in the cell-wall peptidoglycan with glucose present in the whole-cell sugar profile. Strain $\mathrm{S} 1.4^{\top}$ was shown to be a member of either the genus Kribbella or the genus Nocardioides based on a rapid molecular identification method by using single-enzyme restriction endonuclease digestion of the PCR-amplified 16S rRNA gene with Mbol, Vspl, Sphl, SnaBl, Sall and Agel. Analysis of the 16S rRNA gene sequence indicated that strain $S 1.4^{\top}$ belonged to the genus Kribbella. Phylogenetic analysis based on $16 \mathrm{~S}$ rRNA gene sequence comparisons showed that strain $\mathrm{S} 1.4^{\top}$ was related most closely to Kribbella solani $\mathrm{DSA} 1^{\top}$. Strain $\mathrm{S} 1.4^{\top}$ was phenotypically distinct from $K$. solani $\mathrm{DSA} 1^{\top}$ and was shown to be a separate genomic species based on DNA-DNA hybridization experiments (40.4 $\pm 3.8 \%$ DNA-DNA relatedness between the two). Strain S1.4 ${ }^{\top}$ $\left(=\mathrm{DSM} 19227^{\top}=\right.$ NRRL B-24553 ${ }^{\top}$ ) is thus presented as the type strain of a novel species, for which the name Kribbella hippodromi sp. nov. is proposed.
\end{abstract}

The genus Kribbella was proposed by Park et al. (1999) and contains nocardioform actinomycetes with LL-diaminopimelic acid in the cell wall. With the transfer of Hongia koreensis to the genus (Sohn et al., 2003) and more recently the descriptions of Kribbella karoonensis and Kribbella swartbergensis (Kirby et al., 2006) and Kribbella aluminosa (Carlsohn et al., 2007) there are, at the time of writing, 12 recognized Kribbella species (Euzéby, 2007). Here we describe the characterization of a novel member of the genus, isolated from a soil sample collected from a racecourse in the Western Cape, South Africa.

Strain $\mathrm{S} 1.4^{\mathrm{T}}$ was isolated from soil collected in the fynbosrich area surrounded by the horse racing track at Kenilworth Racecourse, Cape Town, South Africa. The soil was ground in a pestle and mortar before being heated at $60{ }^{\circ} \mathrm{C}$ for $1 \mathrm{~h}$, after which $0.1 \mathrm{~g}$ was added to $1 \mathrm{ml}$ of sterile distilled water and agitated by vortexing for $1 \mathrm{~min}$. The sample was serially diluted in sterile distilled water and spread-plated on SM1 agar (Tan et al., 2006) containing cycloheximide $(50 \mu \mathrm{g}$ $\mathrm{ml}^{-1}$ ) and nalidixic acid $\left(10 \mu \mathrm{g} \mathrm{ml}^{-1}\right)$. Strain $\mathrm{S} 1.4^{\mathrm{T}}$ was isolated after incubation at $30{ }^{\circ} \mathrm{C}$ for 21 days and was subsequently maintained on yeast extract-malt extract agar (ISP 2 medium) (Shirling \& Gottlieb, 1966).

Genomic DNA was extracted as described by Wang et al. (1996), with modifications to the lysis buffer to increase the

The GenBank/EMBL/DDBJ accession number for the 16S rRNA gene sequence of strain $S 1.4^{\top}$ is EF472955. lysozyme concentration to $20 \mathrm{mg} \mathrm{ml}^{-1}$ and to include proteinase $\mathrm{K}\left(0.2 \mathrm{mg} \mathrm{ml} \mathrm{ml}^{-1}\right)$; digestion was performed overnight. Treatment with RNase A was performed overnight. To allow rapid identification of the isolate to the genus level, 16S rRNA gene sequence amplification and restriction endonuclease digestion were performed as described by Cook \& Meyers (2003), by using single digestions with the restriction enzymes $M b o \mathrm{I}$ (Sau3AI isoschizomer), VspI (AsnI isoschizomer), SphI, SnaBI, SalI and AgeI. Approximately 500 ng template DNA was used in the PCR amplification. The 16S rRNA gene PCR product was purified by using a Cleanmix kit (TA050CLN; Talent) and then sequenced. Sequence analysis was performed with DNAMAN version 4.13 (Lynnon BioSoft) and phylogenetic analysis was conducted by using MEGA version 3.1 (Kumar et al., 2004).

All International Streptomyces Project (ISP) media were prepared according to Shirling \& Gottlieb (1966). Morphological properties were determined on ISP 2 and inorganic salts-starch agar (ISP 4). Physiological tests were carried out as described by Williams et al. (1989). All plates were incubated at $30{ }^{\circ} \mathrm{C}$, for the recommended periods, unless otherwise stated. Carbon source utilization was tested according to the methods of Shirling \& Gottlieb (1966), with all carbon sources being filter-sterilized and tested at a concentration of $1 \%(\mathrm{w} / \mathrm{v})$, with the exception of sodium acetate, sodium succinate and sodium citrate, which were tested at $0.1 \%(\mathrm{w} / \mathrm{v})$. Nitrogen source utilization was assessed according to Williams et al. (1989). All nitrogen sources were filter-sterilized and tested 
at a concentration of $0.1 \%(\mathrm{w} / \mathrm{v})$. Salt tolerance was determined on ISP 2 medium incubated for 14 days. Antibiotic resistance was tested on Bennett's medium (Atlas, 2004) containing the indicated concentration of antibiotic after incubation for 7 days. Growth at different $\mathrm{pH}$ values ( $\mathrm{pH} \mathrm{4.3,5,7}$ and 9) and at different temperatures $\left(20,30,37\right.$ and $\left.45{ }^{\circ} \mathrm{C}\right)$ was determined on Bennett's medium incubated for 14 days.

The ability to grow under anaerobic conditions was determined on ATCC medium 172 and ISP 9 with glucose as the sole carbon source by incubating the plates at $37^{\circ} \mathrm{C}$ for 21 days in an anaerobic chamber (model 1024; Forma Scientific) containing an atmosphere of $\mathrm{H}_{2} / \mathrm{CO}_{2} / \mathrm{N}_{2}$ $(5: 10: 85)$. Before incubation, plates were opened inside the chamber for $5 \mathrm{~s}$ to remove all residual oxygen and then sealed in a plastic bag.

Chemotaxonomic analysis was conducted as described by Hasegawa et al. (1983) by using freeze-dried cells of a culture grown in ISP 2 medium, with moderate shaking, for 3 days at $30{ }^{\circ} \mathrm{C}$. For analysis of whole-cell sugars, the solvent system used was ethyl acetate/pyridine/distilled water $(100: 35: 25, \mathrm{v} / \mathrm{v})$.

Antimicrobial testing was performed against Mycobacterium aurum $\mathrm{A}+$ in standard agar overlays with 9-day-old stabinoculated cultures of strain S1.4 ${ }^{\mathrm{T}}$ on ISP 2, Difco Middlebrook 7H9 agar (Becton Dickinson) containing $10 \mathrm{mM}$ glucose (albumin-dextrose-catalase supplement omitted), MC agar (Nonomura \& Ohara, 1971) and MC agar containing glycerol as the carbon source. Luria sloppy agar (Sambrook et al., 1989) was used for the overlays.

DNA-DNA hybridization experiments were performed as a service by the DSMZ (Deutsche Sammlung von Mikroorganismen und Zellkulturen) by using the spectrophotometric method of De Ley et al. (1970) and incorporating the modifications of Huß et al. (1983).
Analysis of the 16S rRNA gene restriction fragment patterns of strain $\mathrm{S} 1.4^{\mathrm{T}}$ indicated that it belonged to either the genus Kribbella or the genus Nocardioides (Cook \& Meyers, 2003). A nucleotide-nucleotide BLAST search (Altschul et al., 1997) based on 1389 bp of the 16S rRNA gene sequence indicated that strain $\mathrm{S} 1.4^{\mathrm{T}}$ belonged to the genus Kribbella and was most closely related to Kribbella solani $\mathrm{DSAl}^{\mathrm{T}}(99.57 \%$ similar over $1389 \mathrm{bp}$, by local alignment). This association was confirmed by constructing a neighbour-joining phylogenetic tree (Saitou \& Nei, 1987 ) in which strain S1.4 ${ }^{\mathrm{T}}$ grouped with $K$. solani DSA $1^{\mathrm{T}}$ (Fig. 1). Minimum-evolution and maximum-parsimony (Takahashi \& Nei, 2000) trees were also constructed, which further supported these results (see Fig. 1).

DNA-DNA hybridization experiments between $K$. solani DSA $1^{\mathrm{T}}$ and strain $S 1.4^{\mathrm{T}}$ indicated that these strains shared only $40.4 \pm 3.8 \%$ DNA-DNA relatedness and thus represent two separate genomic species (based on the threshold value of $70 \%$ used to delineate bacterial species; Wayne et al., 1987). Results from the phenotypic characterization of strain $\mathrm{S} 1.4^{\mathrm{T}}$ are given in Table 1 and in the species description.

\section{Description of Kribbella hippodromi sp. nov.}

Kribbella hippodromi (hip.po.dro'mi. Gr. masc. n. hippodromos horse racecourse, N.L. gen. masc. n. hippodromi of/ from a horse racecourse, referring to the source of isolation of the type strain, Kenilworth Racecourse, Cape Town, Western Cape, South Africa).

Cells are Gram-positive and aerobic (unable to grow on ATCC medium 172 or ISP 9 with glucose under anaerobic conditions). Colonies appear convoluted with irregular edges on most media. Vegetative mycelium appears cream in colour with highly branched hyphae, which fragment in both liquid and agar cultures. Aerial mycelium appears white on ISP 4 . No diffusible pigments are produced.

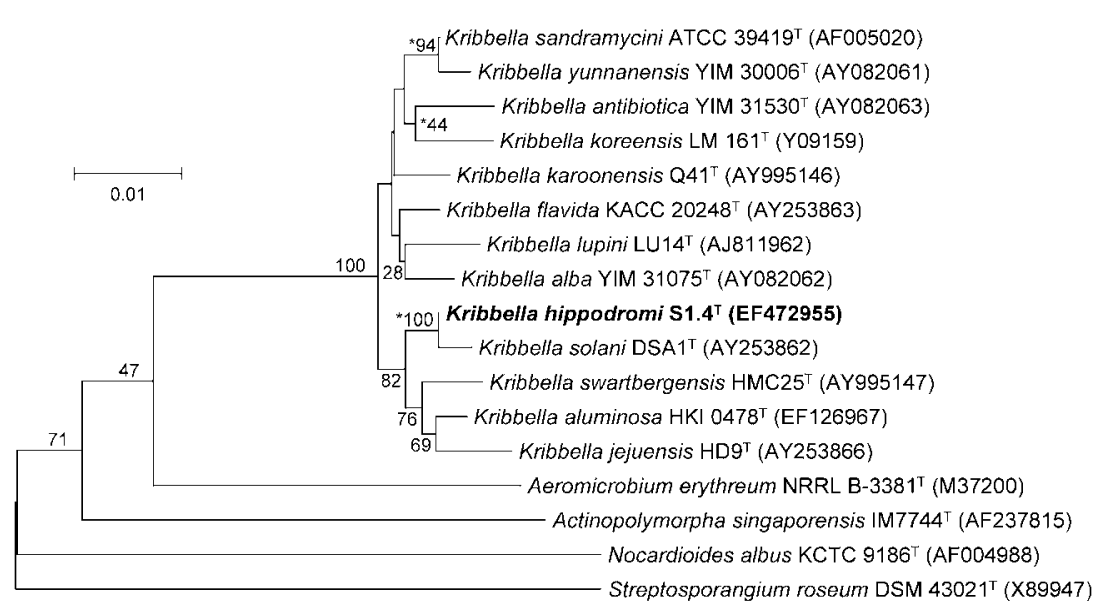

Fig. 1. Unrooted phylogenetic tree showing the position of strain $\mathrm{S} 1.4^{\top}$ within the genus Kribbella and its relationship to other actinomycetes. The tree was constructed by using the neighbour-joining method based on $1369 \mathrm{bp}$ of the $16 \mathrm{~S}$ rRNA gene sequence. Values at nodes are bootstrap percentages based on 1000 replications (only values above $40 \%$ are shown), with asterisks indicating clades that were conserved in the neighbourjoining, minimum-evolution and maximum-parsimony trees. Accession numbers are indicated in parentheses. Actinopolymorpha singaporensis IM7744 ${ }^{\top}$, Aeromicrobium erythreum NRRL B-3381 ${ }^{\top}$, Nocardioides albus KCTC $9186^{\top}$ and Streptosporangium roseum DSM $43021^{\top}$ were used as outgroups. Bar, 1 nucleotide substitution per 100 nucleotides. 
Table 1. Differential phenotypic characteristics between strain $\mathrm{S} 1.4^{\mathrm{T}}$ and closely related Kribbella type strains

Strain: $1, \mathrm{~S} 1.4^{\mathrm{T}} ; 2, K$. solani $\mathrm{DSA} 1^{\mathrm{T}} ; 3, K$. swartbergensis $\mathrm{HMC} 25^{\mathrm{T}}$ (Kirby et al., 2006); 4, K. jejuensis $\mathrm{HD}^{\mathrm{T}}$ (Song et al., 2004); 5, K. aluminosa HKI $0478^{\mathrm{T}}$ (Carlsohn et al., 2007). Conflicting data are indicated in parentheses. ++ , Strongly positive; + , positive; $+\mathrm{W}$, weakly positive; - , negative; ND, no data available; NG, no growth.

\begin{tabular}{|c|c|c|c|c|c|}
\hline Test & 1 & 2 & 3 & 4 & 5 \\
\hline Nitrate reduction & + & + & + & - & - \\
\hline \multicolumn{6}{|l|}{ Degradation of: } \\
\hline Adenine & + & + & + & - & + \\
\hline Casein & + & + & + & - & + \\
\hline Hypoxanthine & + & + & + & $-\left(+^{*}\right)$ & + \\
\hline Tween 80 & + & + & + & - & + \\
\hline Tyrosine & + & + & + & - & + \\
\hline Urea & - & - & NG & + & + \\
\hline Xanthine & - & - & $\mathrm{ND}$ & - & + \\
\hline Hydrolysis of starch & $+\mathrm{w}$ & $+\mathrm{w}$ & + & - & + \\
\hline \multicolumn{6}{|l|}{ Growth at/with: } \\
\hline $37{ }^{\circ} \mathrm{C}$ & + & - & + & + & + \\
\hline $45^{\circ} \mathrm{C}$ & - & - & + & - & - \\
\hline $\mathrm{pH} 4.3$ & $+\mathrm{w}$ & - & $\mathrm{ND}$ & - & $\mathrm{ND}$ \\
\hline pH 9 & + & + & + & - & ND \\
\hline $4 \% \mathrm{NaCl}$ & + & + & $+\mathrm{w}$ & - & - \\
\hline $5 \% \mathrm{NaCl}$ & + & $+\mathrm{w}$ & - & - & - \\
\hline $6 \% \mathrm{NaCl}$ & $+\mathrm{w}$ & - & - & - & - \\
\hline \multicolumn{6}{|c|}{ Utilization as sole carbon source of: } \\
\hline Adonitol & + & + & ND & - & ND \\
\hline myo-Inositol & ++ & + & $+\mathrm{w}$ & - & + \\
\hline Inulin & ++ & - & - & + & ND \\
\hline$\alpha$-Lactose & - & ++ & $+\mathrm{w}$ & + & ND \\
\hline $\mathrm{D}(-)$-Mannitol & + & + & $+\mathrm{w}$ & - & + \\
\hline $\mathrm{D}(+)$-Mannose & + & + & $+\mathrm{w}$ & - & ND \\
\hline Salicin & + & + & $\mathrm{ND}$ & - & ND \\
\hline $\mathrm{D}(+)$-Xylose & - & ++ & $+\mathrm{w}$ & + & + \\
\hline \multicolumn{6}{|c|}{ Utilization as sole nitrogen source of: } \\
\hline DL- $\alpha$-Amino- $n$-butyric acid & $+\mathrm{w}$ & + & $\mathrm{ND}$ & + & ND \\
\hline 4-Hydroxy-L-proline & $+\mathrm{w}$ & + & ND & + & ND \\
\hline L-Methionine & - & + & ND & ND & ND \\
\hline L-Phenylalanine & - & + & ND & ND & ND \\
\hline L-Valine & $+\mathrm{w}$ & ++ & $\mathrm{ND}$ & ND & ND \\
\hline \multicolumn{6}{|l|}{ Growth on ATCC medium 172: } \\
\hline Under aerobic conditions & + & + & ++ & $++^{*}$ & ND \\
\hline Under anaerobic conditions & - & $+\mathrm{w}$ & - & $+\mathrm{w}^{*}$ & ND \\
\hline
\end{tabular}

${ }^{\star}$ Data taken from Kirby et al. (2006).

Melanin is not produced on peptone-yeast extract-iron agar (ISP 6) or on tyrosine agar (ISP 7). Nitrate is reduced to nitrite. Produces $\mathrm{H}_{2} \mathrm{~S}$. Utilizes adonitol, $\mathrm{L}(+)$-arabinose, cellobiose, $\mathrm{D}(-)$-fructose, $\mathrm{D}(+)$-galactose, $\mathrm{D}(+)$-glucose, glycerol, myo-inositol, inulin, maltose, $\mathrm{D}(-)$-mannitol, $\mathrm{D}(+)$-mannose, melezitose, melibiose, raffinose, $\mathrm{L}(+)$ rhamnose, salicin, sucrose and trehalose as sole carbon sources, with weak growth on sodium acetate, sodium citrate and sodium succinate and doubtful growth on $\alpha$ - lactose and $\mathrm{D}(+)$-xylose. Unable to utilize xylitol as a sole carbon source. Utilizes L-arginine, L-asparagine, L-histidine, potassium nitrate and L-threonine as sole nitrogen sources, with weak growth on DL- $\alpha$-amino- $n$-butyric acid, L-cysteine, L-4-hydroxyproline, L-serine and L-valine and doubtful growth on L-methionine and L-phenylalanine. Grows at 20,30 and $37{ }^{\circ} \mathrm{C}$, but not at $45^{\circ} \mathrm{C}$. Grows at $\mathrm{pH} \mathrm{5,7}$ and 9 (weakly at $\mathrm{pH} 4.3$ ). Aesculin and arbutin are hydrolysed, starch is weakly hydrolysed but pectin is not hydrolysed. Adenine, casein, gelatin, hypoxanthine, Tween 80 and L-tyrosine are degraded. Allantoin, cellulose, guanine, urea, xanthine and xylan are not degraded. Grows in the presence of $5 \% \mathrm{NaCl}$, with very weak growth at $6 \% \mathrm{NaCl}$ and no growth at $7 \% \mathrm{NaCl}$. Resistant to lincomycin hydrochloride $\left(100 \mu \mathrm{g} \mathrm{ml}^{-1}\right)$, neomycin sulfate $\left(50 \mu \mathrm{g} \mathrm{ml}^{-1}\right)$, oleandomycin phosphate $\left(100 \mu \mathrm{g} \mathrm{ml} \mathrm{m}^{-1}\right)$, penicillin $\mathrm{G}\left(10 \mathrm{IU} \mathrm{ml} \mathrm{ml}^{-1}\right)$, rifampicin $\left(50 \mu \mathrm{g} \mathrm{ml}^{-1}\right)$ and streptomycin sulfate $\left(100 \mu \mathrm{g} \mathrm{ml}^{-1}\right)$, but sensitive to cephaloridine $\left(100 \mu \mathrm{g} \mathrm{ml}{ }^{-1}\right)$, tobramycin sulfate $(50 \mu \mathrm{g}$ $\left.\mathrm{ml}^{-1}\right)$ and vancomycin hydrochloride $\left(50 \mu \mathrm{g} \mathrm{ml}{ }^{-1}\right)$. No antibacterial activity is detected against M. aurum $\mathrm{A}+$. The cell-wall peptidoglycan contains LL-diaminopimelic acid and glycine (chemotype I of Lechevalier \& Lechevalier, 1970). Glucose and an unidentified sugar are present in the whole-cell sugar hydrolysate.

The type strain, S1.4 $4^{\mathrm{T}}$ (=DSM $19227^{\mathrm{T}}=$ NRRL B-24553 ${ }^{\mathrm{T}}$ ), was isolated from soil from Kenilworth Racecourse, Cape Town, South Africa.

\section{Acknowledgements}

We would like to thank the track managers at Kenilworth Racecourse, Herman Lackay and Jerome Diedericks, for collecting the soil sample, Di James for DNA sequencing, Professor Dr Hans G. Trüper for assistance with naming of the organism and Associate Professors Val Abratt and Shez Reid for use of the anaerobic chamber. G. J. E. holds a Prestigious Scholarship from the National Research Foundation (NRF), a Benfara Scholarship from the University of Cape Town (UCT) and a KW Johnstone Research Scholarship (UCT). This work was supported by research grants to P.R.M. from the Medical Research Council of South Africa, the NRF (grant number 2073133) and the University Research Committee (UCT).

\section{References}

Altschul, S. F., Madden, T. L., Schäffer, A. A., Zhang, J., Zhang, Z., Miller, W. \& Lipman, D. J. (1997). Gapped BLAST and PSI-BLAST: a new generation of protein database search programs. Nucleic Acids Res 25, 3389-3402.

Atlas, R. M. (2004). Handbook of Microbiological Media, 3rd edn. Boca Raton, FL: CRC Press.

Carlsohn, M. R., Groth, I., Spröer, C., Schütze, B., Saluz, H.-P., Munder, T. \& Stackebrandt, E. (2007). Kribbella aluminosa sp. nov., isolated from a medieval alum slate mine. Int J Syst Evol Microbiol 57, 1943-1947.

Cook, A. E. \& Meyers, P. R. (2003). Rapid identification of filamentous actinomycetes to the genus level using genus-specific $16 \mathrm{~S}$ rRNA gene restriction fragment patterns. Int J Syst Evol Microbiol 53, 1907-1915. 
De Ley, J., Cattoir, H. \& Reynaerts, A. (1970). The quantitative measurement of DNA hybridization from renaturation rates. Eur $J$ Biochem 12, 133-142.

Euzéby, J. P. (2007). Kribbella Park et al. 1999, gen. nov. In List of Prokaryotic Names with Standing in Nomenclature. http://www. bacterio.cict.fr/ijk/kribbella.html

Hasegawa, T., Takizawa, M. \& Tanida, S. (1983). A rapid analysis for chemical grouping of aerobic Actinomycetes. J Gen Appl Microbiol 29, 319-322.

Huß, V. A. R., Festl, H. \& Schleifer, K. H. (1983). Studies on the spectrophotometric determination of DNA hybridization from renaturation rates. Syst Appl Microbiol 4, 184-192.

Kirby, B. M., Le Roes, M. \& Meyers, P. R. (2006). Kribbella karoonensis sp. nov. and Kribbella swartbergensis sp. nov., isolated from soil from the Western Cape, South Africa. Int J Syst Evol Microbiol 56, 1097-1101.

Kumar, S., Tamura, K. \& Nei, M. (2004). MEGA3: integrated software for molecular evolutionary genetics analysis and sequence alignment. Brief Bioinform 5, 150-163.

Lechevalier, M. P. \& Lechevalier, H. (1970). Chemical composition as a criterion in the classification of aerobic actinomycetes. Int J Syst Bacteriol 20, 435-443.

Nonomura, H. \& Ohara, Y. (1971). Distribution of actinomycetes in soil. VIII. Green spore group of Microtetraspora, its preferential isolation and taxonomic characteristics. J Ferment Technol 49, 1-7.

Park, Y. H., Yoon, J. H., Shin, Y. K., Suzuki, K., Kudo, T., Seino, A., Kim, H., Lee, J. S. \& Lee, S. T. (1999). Classification of 'Nocardioides fulvus' IFO 14399 and Nocardioides sp. ATCC 39419 in Kribbella gen. nov., as Kribbella flavida sp. nov. and Kribbella sandramycini sp. nov. Int J Syst Bacteriol 49, 743-752.

Saitou, N. \& Nei, M. (1987). The neighbor-joining method: a new method for reconstructing phylogenetic trees. Mol Biol Evol 4, 406-425.
Sambrook, J., Fritsch, E. F. \& Maniatis, T. (1989). Bacterial media, antibiotics and bacterial strains. In Molecular Cloning: a Laboratory Manual, 2nd edn, pp. A.1-A.13. Cold Spring Harbor, NY: Cold Spring Harbor Laboratory.

Shirling, E. B. \& Gottlieb, D. (1966). Methods for characterization of Streptomyces species. Int J Syst Bacteriol 16, 313-340.

Sohn, K., Hong, S. G., Bae, K. S. \& Chun, J. (2003). Transfer of Hongia koreensis Lee et al. 2000 to the genus Kribbella Park et al. 1999 as Kribbella koreensis comb. nov. Int J Syst Evol Microbiol 53, 1005-1007.

Song, J., Kim, B. Y., Hong, S. B., Cho, H. S., Sohn, K., Chun, J. \& Suh, J. W. (2004). Kribbella solani sp. nov. and Kribbella jejuensis sp. nov., isolated from potato tuber and soil in Jeju, Korea. Int J Syst Evol Microbiol 54, 1345-1348.

Takahashi, K. \& Nei, M. (2000). Efficiencies of fast algorithms of phylogenetic inference under the criteria of maximum parsimony, minimum evolution, and maximum likelihood when a large number of sequences are used. Mol Biol Evol 17, 1251-1258.

Tan, G. Y. A., Ward, A. C. \& Goodfellow, M. (2006). Exploration of Amycolatopsis diversity in soil using genus-specific primers and novel selective media. Syst Appl Microbiol 29, 557-569.

Wang, Y., Zhang, Z. \& Ruan, J. (1996). A proposal to transfer Microbispora bispora (Lechevalier 1965) to a new genus, Thermobispora gen. nov., as Thermobispora bispora comb. nov. Int $J$ Syst Bacteriol 46, 933-938.

Wayne, L. G., Brenner, D. J., Colwell, R. R., Grimont, P. A. D., Kandler, O., Krichevsky, M. I., Moore, L. H., Moore, W. E. C., Murray, R. G. E. \& other authors (1987). International Committee on Systematic Bacteriology. Report of the ad hoc committee on reconciliation of approaches to bacterial systematics. Int J Syst Bacteriol 37, 463-464.

Williams, S. T., Goodfellow, M. \& Alderson, G. (1989). Genus Streptomyces Waksman and Henrici 1943, 339 ${ }^{\mathrm{AL}}$. In Bergey's Manual of Systematic Bacteriology, vol. 4, pp. 2452-2492. Edited by S. T. Williams, M. E. Sharpe \& J. G. Holt. Baltimore: Williams \& Wilkins. 